\title{
Risk of lung cancer among masons in Iceland
}

\author{
Vilhjalmur Rafnsson, Holmfridur Gunnarsdottir, Mirja Kiilunen
}

\begin{abstract}
Objectives-To estimate the risk of gastrointestinal cancer and lung cancer in a cohort of masons exposed to cement and hexavalent chromium by a follow up in the Icelandic Cancer Registry.

Methods-The cohort, 1172 men, was defined as those who had served their apprenticeship and were fully licensed as masons (cement finishers) in Iceland, were born after 1880 and were alive in 1955. The men were exposed to an aerosol of wet concrete, particularly when spraying. According to the analyses of urinary chromium the masons were exposed to hexavalent chromium. A computer file on masons was record linked to the Cancer Registry by making use of the personal identification numbers. Expected cancer incidence was calculated on the basis of number of person-years for each fiveyear age category during the individual calendar years of the study period and multiplied by the specific incidence for cause and calendar year for men in Iceland provided by the Cancer Registry. Results-The standardised incidence ratio (SIR) for all cancers was 1.13 in the total cohort and 1.33 when allowance was made for 30 years to elapse before starting to count person years of risk. The risk for gastrointestinal cancers was not increased. The SIR for lung cancer was 1.69 in the total cohort and 1.77 when a lag of 30 years was included. The SIR for lung cancer among those born in 1920 or later was 1.86. Results from a postal questionnaire showed that fewer masons had never smoked and more masons had stopped smoking than the controls from the general population.

Conclusion-The increased risk of lung cancer among the masons may be related to their work. The exposure information, although limited, supports the suggestion that hexavalent chromium in the cement may be the causal link, as information on the smoking habits indicate that the control for this important possible confounder is adequate.
\end{abstract}

(Occup Environ Med 1997;54:184-188)

Keywords: hexavalent chromium; cancer registry; cement finishing

The possible carcinogenic effect of silicate cement has been considered in several recent studies. ${ }^{1-11}$ Of these, the cohort studies deal with cement manufacturers ${ }^{125}$ and masons, ${ }^{3}$ and attention has focused on stomach cancer, lung cancer, and colon cancer. The case-control studies have focused on gastrointestinal cancer, ${ }^{9}$ laryngeal cancer, ${ }^{6}$ squamous cell carcinoma of the upper aerodigestive tract, ${ }^{7810}$ and lung cancer. ${ }^{11}$ Censuses and register based studies have found increased risk of lung and laryngeal cancer among workers exposed to cement and concrete. ${ }^{12-16}$

In a former study it was suggested that exposure to hexavalent chromium may be causally related to lung cancer in Icelandic masons. ${ }^{3}$ The results from this single study on lung cancer ${ }^{3}$ do not allow one to draw a definite conclusion ${ }^{17}$ and others cast serious doubt on the possible risk of lung cancer among cement workers. ${ }^{4}$ In case-control studies the risk of cancer of the mouth, oropharynx, hypopharynx, and larynx was associated with cement dust and it was argued that hexavalent chromium was involved. ${ }^{6710}$ When discussing carcinogenicity of chromium and its salts it has been stated that carcinogenic risk should be related to a working process or to a group of metal compounds rather than to a single substance. ${ }^{18}$ Hexavalent chromium has been classified as carcinogenic to humans. ${ }^{19}$

In this study we followed up a cohort of masons in the Icelandic Cancer Registry for particularly gastrointestinal cancer and lung cancer. The cohort is an extention of the former study. ${ }^{3}$

\section{Material and methods}

This is a retrospective cohort study. The cohort was defined as all those who had served their apprenticeship and were fully licensed as masons (cement finishers) in Iceland, were born after 1880, and were alive in 1955. Stone cutters were excluded. In the previous study of masons in Iceland $^{3}$ the information on the masons was obtained from the published Register of Masons and Stone Cutters (Múraratal og steinsmiða). ${ }^{20} \mathrm{~A}$ new register was published in $1993^{21}$ which allowed an enlargement of the group. ${ }^{3}$ The Masons' Union in Reykjavik and the Masons' Employer's Association in Reykjavik took the initiative and carried out the work of compiling these registers ${ }^{20}{ }^{21}$ without the intervention of the authors of the studies. This register was used to compile a computer file of the masons. Permission was obtained from the Data Protection Commission to produce this file and to link the records with other registers. A 
survey of smoking habits and working years was made in agreement with the union and the employers.

The study population was 1172 men. Information in the Register of Masons and Stone Cutters included the man's name, date of birth, and the year he became licensed as a mason. The name and date of birth were used to find the personal identification number in the National Registry, which consists of the date of birth and an additional four digit number. The National Registry includes all people who have lived in Iceland since 1951. Death or emigration is registered; no person had emigrated during the study period. The personal identification numbers were used to link records with the National Registry, and to discover typographical errors. In this way it was possible to define person-years at risk for each man. The risk period for each man started in 1955 , or the year he was licensed as a mason if later than 1955. The risk period lasted to the end of 1993 or to the date of death, whichever came first. In this way person-years were registered within five-year age categories during the individual calendar years of the study period 1955-93.

The cohort was divided by year of birth. Those born in 1920 or later became licensed at the average age of 27 years, those born in 1919 or before at 32 . This birth specific analysis was intended to evaluate the risk associated with recent exposure as there was no information on individual exposure.

The Cancer Registry in Iceland is a nation wide register of cancer cases established in 1955. More than $92 \%$ of cases were verified by histological diagnosis. ${ }^{22}$ Every case was registered by its personal identification number according to the seventh revision of the International Classification of Diseases (ICD7). The computer file on masons was linked to the Cancer Registry by making use of the personal identification numbers. Thus we were able to establish whether the men had cancer or not, and if they had cancer, the cancer site.

The number of expected cancers was calculated on the basis of number of person-years for each five-year age category during the individual calendar years of the study period and multiplied by incidences for males in Iceland specific for the cause and calendar year provided by the Cancer Registry. ${ }^{22}$ The ratios between the observed and expected numbers of cancers, the standardised incidence ratio (SIR), were calculated with $95 \%$ confidence

Table 1 Accumulated years of work at cement finishing and tile setting floors and walls from responses of 569 masons

\begin{tabular}{lcc}
\hline Duration of work $(y)$ & $\begin{array}{l}\text { Cement finishing } \\
n(\%)\end{array}$ & $\begin{array}{l}\text { Tile setting } \\
n(\%)\end{array}$ \\
\hline Never & $17(3 \cdot 0)$ & $166(29 \cdot 2)$ \\
Ever: & $552(97 \cdot 0)$ & $403(70 \cdot 8)$ \\
$>2$ & $551(96 \cdot 8)$ & $326(57 \cdot 3)$ \\
$>10$ & $502(88 \cdot 2)$ & $107(18 \cdot 8)$ \\
$>20$ & $367(64 \cdot 5)$ & $41(7 \cdot 2)$ \\
$>30$ & $220(38 \cdot 7)$ & $21(3 \cdot 7)$ \\
$>40$ & $97(17 \cdot 0)$ & $7(1 \cdot 2)$ \\
\hline
\end{tabular}

intervals (95\% CIs), assuming a Poisson distribution and making use of Byar's approximation. ${ }^{23}$

A special survey on smoking habits among the cohort members who were alive and could be located was undertaken in 1995 with a postal questionnaire. The participation rate was $71 \cdot 4 \%$. The results of a nationwide survey (participation rate $73 \%$ ) on smoking habits conducted in 1995 by the Committee for Tobacco Use Prevention, where the same questionnaire was used, served as a comparison. ${ }^{24}$

Besides the questions on smoking habits, the masons were asked about the number of years they had worked at cement finishing and tile setting (table 1 ). Only 3\% said that they had never done any cement finishing which means that they probably did not work as masons after their apprenticeships. Table 1 shows that cement finishing was the main task of those who answered the questionnaire and it seems sensible to conclude from the figures that the masons remained in their profession for several years.

The working tasks of the Icelandic masons have been described before. ${ }^{3}$ Their main job is to finish and smooth the surfaces of concrete structures, as more than $90 \%$ of houses of more than one storey in Iceland are built of reinforced concrete due to the danger from earthquakes. The concrete used to smooth the walls, ceilings, and floors inside and outside buildings is made of cement, sand, water, and small amounts of different compounds which are added to the mixtures. ${ }^{25}$ The mixing of the concrete is done in a mixer fed and operated on by the assistant. Masons usually work in teams of two to five per assistant. If the team has no assistant, which is infrequent, the youngest of the masons in the team takes care of the concrete mixing. Mixing the concrete involves exposure to cement dust. During short preparatory periods before applying the wet concrete the masons are sometimes exposed to dry concrete dust, but more often the assistant has that task. Wet concrete is applied with a trowel or by spraying with a vacuum pump. The spraying produces a thick mist of wet concrete spray, so if working inside, it is difficult to see across the room. This is an aerosol of wet concrete. Respirator masks are used only spasmodically. Dermal contact with the wet concrete is intensive, particularly on the hands and face.

The concentration of hexavalent chromium in Icelandic cement in 1983 was 5.8$9.4 \mathrm{mg} / \mathrm{kg} .{ }^{26}$ After the use of ferrous sulphate as a reduction agent began in 1992, the hexavalent chromium content dropped to less than $2 \mathrm{mg} / \mathrm{kg}{ }^{27}$ In the year 1987 the mean concentration of total dust in the air, measured in personal samples from eight masons over a three day period was $16.3 \mathrm{mg} / \mathrm{m}^{3}$. The highest concentration was measured while the masons were spraying. The amount of total chromium in the samples ranged from the detection limits of $0.003 \mathrm{mg} / \mathrm{m}^{3}$ to $0.008 \mathrm{mg} / \mathrm{m}^{3}$. In 10 samples of drinking water taken in the Reykjavik area in 1987 the concentration of chromium 
Table 2 Observed and expected number of cancers among 1172 masons 1955-93

\begin{tabular}{|c|c|c|c|}
\hline Cancer sites (ICD-7) & Obs & $\operatorname{Exp}$ & $\operatorname{SIR}(95 \% C I)$ \\
\hline All cancers $(140-205)$ & 148 & $130 \cdot 55$ & $1.13(0.96$ to 1.33$)$ \\
\hline Lips (140) & 2 & $2 \cdot 31$ & $0.87(0.10$ to 3.13$)$ \\
\hline Oesophagus (150) & 3 & $2 \cdot 62$ & $1.15(0.23$ to 3.35$)$ \\
\hline Stomach $(151)$ & 21 & $19 \cdot 47$ & $1.08(0.67$ to 1.65$)$ \\
\hline Small intestine (152) & 3 & 0.71 & $4.23(0.85$ to 12.35$)$ \\
\hline Colon (153) & 5 & 8.91 & $0.56(0.18$ to 1.31$)$ \\
\hline Rectum (154) & 4 & 3.79 & $1.06(0.28$ to 2.70$)$ \\
\hline Pancreas (157) & 7 & $4 \cdot 71$ & $1.49(0.60$ to 3.06$)$ \\
\hline Larynx (161) & 3 & 1.63 & $1.84(0.37$ to 5.38$)$ \\
\hline Lung (162) & 25 & $14 \cdot 81$ & $1.69(1.09$ to 2.49$)$ \\
\hline Prostate (177) & 25 & $24 \cdot 13$ & $1.04(0.67$ to 1.53$)$ \\
\hline Kidney $(180)$ & 10 & $7 \cdot 16$ & $1.40(0.67$ to 2.57$)$ \\
\hline Other urinary organs $(181)$ & 10 & $8 \cdot 45$ & $1.18(0.57$ to 2.18$)$ \\
\hline Other skin (191) & 2 & 2.98 & $0.67(0.08$ to 2.42$)$ \\
\hline Brain (193) & 3 & $4 \cdot 13$ & $0.73(0.15$ to 2.12$)$ \\
\hline Thyroid gland (194) & 4 & 2.63 & $1.52(0.41$ to 3.89$)$ \\
\hline \multicolumn{4}{|l|}{ Lymphosarcoma and } \\
\hline reticulosarcoma (200) & 2 & $2 \cdot 76$ & $0.72(0.08$ to 2.62$)$ \\
\hline Multiple myeloma (203) & 2 & 1.71 & $1.17(0.13$ to 4.22$)$ \\
\hline Leukaemia (204) & 4 & 3.02 & $1.32(0.36$ to 3.39$)$ \\
\hline
\end{tabular}

Table 3 Observed and expected number of cancers among 1060 masons with a 10 y lag between finishing vocational training and counting person-years

\begin{tabular}{|c|c|c|c|}
\hline Cancer sites (ICD-7) & Obs & $\operatorname{Exp}$ & $\operatorname{SIR}(95 \% C I)$ \\
\hline All cancers $(140-205)$ & 140 & $123 \cdot 56$ & $1.13(0.95$ to 1.34$)$ \\
\hline Lips (140) & 1 & $2 \cdot 22$ & $0.45(0.01$ to 2.51$)$ \\
\hline Oesophagus (150) & 3 & $2 \cdot 53$ & $1.19(0.24$ to 3.46$)$ \\
\hline Stomach (151) & 19 & $18 \cdot 58$ & $1.02(0.62$ to 1.60$)$ \\
\hline Small intestine (152) & 3 & 0.65 & $4.62(0.93$ to 13.49$)$ \\
\hline Colon (153) & 4 & $8 \cdot 6$ & $0.47(0.13$ to 1.19$)$ \\
\hline Rectum (154) & 4 & $3 \cdot 52$ & $1.14(0.31$ to 2.91$)$ \\
\hline Pancreas (157) & 7 & $4 \cdot 52$ & $1.55(0.62$ to 3.19$)$ \\
\hline Larynx (161) & 3 & 1.56 & $1.92(0.39$ to 5.62$)$ \\
\hline Lung (162) & 23 & $14 \cdot 11$ & $1.63(1.03$ to 2.45$)$ \\
\hline Prostate (177) & 25 & $23 \cdot 75$ & $1.05(0.68$ to 1.55$)$ \\
\hline Kidney (180) & 9 & $6 \cdot 8$ & $1.32(0.60$ to 2.51$)$ \\
\hline Other urinary organs (181) & 9 & $8 \cdot 11$ & $1.11(0.51$ to 2.11$)$ \\
\hline Other skin (191) & 2 & $2 \cdot 87$ & $0.70(0.08$ to 2.52$)$ \\
\hline Brain (193) & 3 & $3 \cdot 6$ & $0.83(0.17$ to 2.43$)$ \\
\hline Thyroid gland (194) & 4 & $2 \cdot 36$ & $1.69(0.46$ to 4.34$)$ \\
\hline \multicolumn{4}{|l|}{ Lymphosarcoma and } \\
\hline reticulosarcoma (200) & 2 & $2 \cdot 52$ & $0.79(0.09$ to 2.87$)$ \\
\hline Multiple myeloma (203) & 2 & $1 \cdot 66$ & $1.20(0.14$ to 4.35$)$ \\
\hline Leukaemia (204) & 4 & $2 \cdot 71$ & $1.48(0.40$ to 3.78$)$ \\
\hline
\end{tabular}

Table 4 Observed and expected number of cancers among 525 masons with a 30 y lag between finishing vocational training and counting person-years

\begin{tabular}{|c|c|c|c|}
\hline Cancer sites (ICD-7) & Obs & $\operatorname{Exp}$ & $\operatorname{SIR}(95 \% C I)$ \\
\hline All cancers (140-205) & 109 & $81 \cdot 9$ & $1.33(1.09$ to 1.61$)$ \\
\hline Lips $(140)$ & 1 & $1 \cdot 48$ & $0.68(0.01$ to 3.76$)$ \\
\hline Oesophagus (150) & 3 & $1 \cdot 77$ & $1.69(0.34$ to 4.95$)$ \\
\hline Stomach (15i) & 15 & $11 \cdot 81$ & $1.27(0.71$ to 2.09$)$ \\
\hline Small intestine (152) & 2 & $0 \cdot 38$ & $5.26(0.59$ to 19.00$)$ \\
\hline Colon (153) & 3 & $5 \cdot 92$ & $0.51(0.10$ to 1.48$)$ \\
\hline Rectum (154) & 4 & $2 \cdot 45$ & $1.63(0.44$ to 4.18$)$ \\
\hline Pancreas (157) & 5 & $3 \cdot 1$ & $1.61(0.52$ to 3.76$)$ \\
\hline Larynx (161) & 3 & 0.95 & $3.16(0.63$ to 9.23$)$ \\
\hline Lung (162) & 16 & $9 \cdot 02$ & $1.77(1.01$ to 2.88$)$ \\
\hline Prostate (177) & 24 & $19 \cdot 01$ & $1.26(0.81$ to 1.88$)$ \\
\hline Kidney (180) & 6 & $4 \cdot 29$ & $1.40(0.51$ to 3.04$)$ \\
\hline Other urinary organs (181) & 6 & $5 \cdot 33$ & $1.13(0.41$ to 2.45$)$ \\
\hline Other skin (191) & 1 & $2 \cdot 05$ & $0.49(0.01$ to 2.71$)$ \\
\hline Brain (193) & 1 & $1 \cdot 6$ & $0.63(0.01$ to 3.48$)$ \\
\hline Thyroid gland (194) & 3 & $1 \cdot 21$ & $2.48(0.50$ to 7.24$)$ \\
\hline \multirow{4}{*}{$\begin{array}{l}\text { Lymphosarcoma and } \\
\text { reticulosarcoma }(200) \\
\text { Multiple myeloma (203) } \\
\text { Leukaemia (204) }\end{array}$} & & & \\
\hline & 2 & 1.43 & $1.40(0.16$ to 5.05$)$ \\
\hline & 2 & $1 \cdot 13$ & $1.77(0.20$ to 6.39$)$ \\
\hline & 3 & 1.64 & $1.83(0.37$ to 5.34$)$ \\
\hline
\end{tabular}

Table 5 Observed and expected number of all cancers and lung cancer according to year of birth

\begin{tabular}{llrl}
\hline Cancer sites $(I C D-7)$ & Obs & Exp & SIR (95\% CI) \\
\hline Born 1920 or later $(\mathrm{n}=895):$ & & & \\
$\quad$ All cancers $(140-205)$ & 49 & 46.95 & $1.04(0.77$ to 1.38$)$ \\
$\quad$ Lung cancer $(162)$ & 12 & 6.46 & $1.86(0.96$ to 3.25$)$ \\
Born 1919 or before $(\mathrm{n}=277):$ & 99 & 83.42 & $1.19(0.96$ to 1.44$)$ \\
$\quad$ All cancers $(140-205)$ & 13 & 8.33 & $1.56(0.83$ to 2.67$)$ \\
Lung cancer $(162)$ & & & \\
\hline
\end{tabular}

Table 6 Smoking habits of a random sample of Icelandic men $(n=1252)$ in 1995 and of masons $(n=569)$ according to a survey in 1995

\begin{tabular}{lll}
\hline Smoking category & $\begin{array}{l}\text { Population sample } \\
n(\%)\end{array}$ & $\begin{array}{l}\text { Masons } \\
n(\%)\end{array}$ \\
\hline Never smoked & $457(36 \cdot 5)$ & $144(25 \cdot 3)$ \\
Stopped smoking: & $305(24 \cdot 4)$ & $231(40 \cdot 6)$ \\
$\quad$ > 1 y ago & $53(4 \cdot 2)$ & $12(2 \cdot 3)$ \\
< 1 y ago & $78(6 \cdot 2)$ & $30(5 \cdot 3)$ \\
Smoker not daily & $358(28 \cdot 6)$ & $135(23 \cdot 7)$ \\
Smoker daily &
\end{tabular}

ranged from 0.011 to $0.017 \mu \mathrm{mol} / 1$. In the geothermal hot water distributed to homes in Reykjavik and used for bathing and washing, the chromium concentration was less than $0.001 \mu \mathrm{mol} / \mathrm{l}$. Drinking water is used in the concrete mixing. In 1987 chromium was measured in urine specimens. ${ }^{28}$ Six masons supplied urine specimens on Monday morning and Thursday afternoon to span the exposure during the week. The resulting concentrations were corrected to a relative density of $1 \cdot 024 .^{29}$ The urinary chromium concentration ran from 0.0084 to $0.0367 \mu \mathrm{mol} / 1$. The contents were higher on Thursday afternoon and a comparison of the Monday and Thursday values with a paired $t$ test indicated a significant difference at the $5 \%$ level $\left(t_{5}=3 \cdot 29\right)$. In 1992 , after the reduction of the hexavalent chromium to trivalent chromium with ferrous sulphate was introduced at the cement plant in Iceland, a similar series of measurements of urinary chromium concentration from 14 masons did not show significant differences between the Monday and Thursday samples $\left(t_{13}=1 \cdot 16\right) .{ }^{30}$ The results of the analysis from 1987 indicated that the masons were at that time exposed to hexavalent chromium, which we were not able to reproduce in the 1992 analysis.

\section{Results}

Table 2 shows the observed and expected number of cancer cases, the SIRs, and the 95\% CIs for selected cancer sites. The SIRs for lung cancer and for cancer of the small intestine were increased.

Tables 3 and 4 show cancer rates with 10 and 30 year lags before counting person-years. In these analyses the SIR for lung cancer was increased and when 30 years elapsed before the counting of person-years started the SIR for all cancers was $1 \cdot 33$.

Table 5 shows the SIRs (95\% CIs) and the observed and expected numbers of all cancers and lung cancer according to year of birth. The SIR for lung cancer was higher among the masons born in 1920 or after.

Table 6 shows the smoking habits among masons and a random sample of Icelandic men from a survey in 1995. There were fewer never smokers but more ex-smokers among the masons than among the general population.

Discussion

Our study confirms the excess of lung cancer previously found in a mortality study of 
masons in Iceland. ${ }^{3}$ There was a moderate increase in the SIRs for lung cancer with a longer lag period before the counting of person-years began. This agrees with what was found for deaths from all causes, from all cancers, and from lung cancer in the previous study. ${ }^{3}$

Our cohort includes some of the same men as the previous study. ${ }^{3}$ The number of men under study has increased from 450 to 1172 . These two studies also have different end points. The previous study reported nine deaths from lung cancer, now there are 25 lung cancer cases. The follow up period is also different, the mortality was followed up from 1951 to 1982 , whereas the follow up of the cancer incidence was 1955 to 1993.

It should be considered as a strength of the study that the gathering of the cohort was done independently of those working on the study. This should secure unbiased development of the cohort, which was based on the authorities' lists of men who had been licensed as masons. Another strength of the study is the use of the Icelandic Cancer Registry. A high proportion of the cases in the Icelandic Cancer Registry have a histologically confirmed diagnosis. ${ }^{22}$ The personal identification number was used for finding the cases in the registry, which gave very dependable results and it also supplied the cancer incidences for Icelandic men which provided the basis for the expected values. The information on cases and the control population was obtained in exactly same way, thus any bias that may occur in the collection of information on cancer should affect equally the observed and the expected values. Owing to the universal use of the personal identification numbers in Iceland, the comprehensive population registry, and the Cancer Registry, a $100 \%$ follow up was ascertained. As lung cancer is common, its expected numbers are quite stable - even in the population of Iceland, which numbers only 260000 .

The main weakness of this study is the lack of more detailed information on exposure. The vocational training to become a licensed mason in Iceland takes four years, which should be looked up on as a minimum exposure time in masonry, and which was served by every man before he entered the study. The survey of the number of years the men had worked as cement finishers indicates that most of the men who responded practised their profession for decades after their apprenticeship. Although limited, the analyses of exposure and urine samples indicate that the men were exposed to hexavalent chromium in the year 1987 before reduction with ferrous sulphate was introduced.

The differences in the activity of the various compounds of chromium may be related to their biological availability. Working with cement is an example of a situation involving mixed exposure to chromium and its compounds. The chemical and physical characteristics of the hexavalent form are most important because it readily crosses cell membranes. Chromate sensitisation plays an important part in the development of allergic contact dermatitis in cement work and ferrous sulphate has been used to reduce chemically the water soluble chromates in cement. ${ }^{31}$ No information on chromate dermatitis among Icelandic masons is available. A recent study on hexavalent chromium concentrations in cement, wet concrete, and dry concrete showed the highest concentration in wet concrete and lowest in dry concrete, and that ferrous sulphate significantly reduced hexavalent chromium concentrations in fresh cement and wet and dry concrete. ${ }^{25}$

No cohort study has found anything but non-significant excesses of lung cancer among cement manufacturers. ${ }^{145}$ The census based studies have shown an excess of lung cancer among construction workers, ${ }^{12} 13$ masons, ${ }^{14}$ plasterers, ${ }^{14} 15$ and reinforced concreters. ${ }^{15}$ In the case-control study of Siemiatycki et $a l^{11}$ an increased risk for lung cancer was found among those exposed to cement or concrete dust. This finding was possibly confounded by simultaneous exposure to silica, and in the case of exposure to cement the finding was concentrated on lorry drivers, ${ }^{11}$ who have in another study been found to have an excess mortality from lung cancer. ${ }^{32}$

The results from the study by Pukkala ${ }^{16}$ support our finding on lung cancer, as it showed increased risk among reinforced concreters, the SIR was above three and the SIRs for lung cancer were also high among other occupations involved with cement work, such as bricklayers, tile setters, and concrete or cement shutters. The highest SIR for squamous cell lung carcinoma was found among reinforced concreters $(5 \cdot 97) .{ }^{16}$ This is interesting in the light of the findings from the study of Siemiatycki et $a l^{11}$ which was on non-adenomous lung cancer.

In their small study of cement manufacturers, ${ }^{4}$ however, Vestbo et al found an increased risk ratio among cement workers in comparison with population controls but did not find it in comparison with their local controls, who also had an increased risk of lung cancer. ${ }^{4}$ They also found a higher risk of lung cancer among workers with over 20 years of exposure than among those with less exposure. All the 95\% CIs of men exposed to cement, however, included unity. ${ }^{4}$

Our analysis of the cohort by year of birth shows that the risk of lung cancer affected the younger masons. This implies that the possible worksite risk of lung cancer is a matter of concern for the younger masons as well as the older, indicating that this does not merely affect the past. In the older portion of the cohort there may be many unrecognised cases that occurred before 1955 .

Although the SIRs for laryngeal cancer were increased they were based on only three cases in this small study, with wide CIs. The case control studies on cancers of the upper aerodigestive $\operatorname{tract}^{6-810}$ that had excesses of these cancers among workers exposed to cement support our findings, and they also suggest that hexavalent chromium in the cement may play a part in the aetiology of these types of cancers. ${ }^{6710}$ 
In this study, we did not find a clear excess of stomach cancer as was found in a cohort study by $\mathrm{McDowall},{ }^{1}$ which was also not confirmed in a study from the United States. ${ }^{2}$ Neither was there an excess of colon cancer as was found for the right colon in the Swedish cohort and case control studies. ${ }^{59}$ On the other hand, there was an unexpected excess incidence of cancer of the small intestine which was based on only three cases.

The information on smoking among the masons and the Icelandic population sample provides a tool to evaluate the possible confounding due to smoking of the results on incidence of lung cancer. ${ }^{33}$ Assuming the risk of lung cancer to be one for non-smokers, five for ex-smokers, and 10 for smokers, we get the predictive value of $(5 \cdot 3 / 5 \cdot 3)=1 \cdot 0$. A more conservative method is to combine the exsmokers and the smokers and recalculate the predictive value assuming the risk to be 10 as for smokers, $(7 \cdot 7 / 6 \cdot 7)=1 \cdot 15$. Thus the excess of lung cancer found in the present cohort of masons is unlikely to be explained by confounding due to smoking. ${ }^{22} 33$

Exposure to silica might be a possible confounding factor, as well as tobacco smoking, in this study. ${ }^{11}$ The evidence that silica is carcinogenic is strongest from cohorts of patients with silicosis. No deaths from silicosis have been found in this cohort.

There is an increase in the risk of lung cancer with increasing time (not necessarily continuous) since first employment. The $95 \%$ CIs for the risk of lung cancer are narrow and do not include unity. There are also increasing trends with increasing latency for cancer of the larynx, small intestine, oesophagus, thyroid gland, and cancers of the lymphatic and haematopoietic tissues. The increased risk for all cancers reached 1.33 with narrow $95 \%$ CIs when 30 years latency was applied.

We conclude that the increased risk of lung cancer among the masons may be related to their work. The exposure information, although limited, supports the suggestion that hexavalent chromium in the cement may be the causal link, as the findings about smoking habits indicate that controlling for this important possible confounder is adequate.

We thank the Masons' Union in Reykjavik and the Masons' Employers Association in Reykjavik for their kind cooperation in conducting this study. We thank Dr Antero Aitio for his comments on the manuscript.

1 McDowall ME. A mortality study of cement workers. $\operatorname{Br} \mathcal{F}$ Ind Med 1984;41:179-82.

2 Amandus HE. Mortality from stomach cancer in United States cement plant and quarry workers, $1950-80 . \mathrm{Br} \mathcal{F}$ Ind Med 1986;43:526-8.

3 Rafnsson V, Johannesdottir SG. Mortality among masons in Iceland. Br $\mathcal{F}$ Ind Med 1986;43:522-5.

4 Vestbo J, Knudsen KM, Raffi E, Korsgaard B, Rasmussen FV. Exposure to cement dust at a Portland cement factory and the risk of cancer. $B r \mathcal{F}$ Ind Med 1991;48:803-7. 5 Jakobsson K, Horstmann V, Welinder H. Mortality and cancer morbidity among cement workers. $\mathrm{Br} \mathcal{f}$ Ind $\mathrm{Med}$ 1993;50:264-72.

6 Maier H, Gewelke U, Dietz A, Thamm H, Heller WD, Weidauer $H$. Kehlkopfkarzinom und BerufstätigkeitErgebnisse der Heidelberger Kehlkopfkrebsstudie. HNO 1992;40:44-51.

7 Maier H, Dietz A, Gewelke U, Heller WD. Berufliche Exposition gegenüber Schadstoffen und Krebsrisiko im Bereich von Mundhöhle, Oropharynx, Hypopharynx und Larynx. Eine Fall-Kontrollstudie. Laryngorhinootoogie 1991;70:93-8.

8 Cauvin JM, Guénel P, Luce $D$, Brugére J, Leclerc A. Occupational exposure and head and neck carcinoma. Clin Otolaryngol 1990;15:439-45.

9 Jakobsson K, Attewell R, Hultgren B, Sjoland $\mathrm{K}$. Gastrointestinal cancer among cement workers. A casereferent study. Int Arch Occup Environ Health 1990; 62:337-40.

10 Maier H, Dietz A, Zielinski D, Jünemann KH, Heller WD. Risikofaktoren bei Plattenepithelkarzinomen der Mundhöhle, des Oropharynx, des Hypopharynx und des Larynx. Disch Med Wochenschr 1990;115:843-50.

11 Siemiatycki J, Dewar R, Lakhani R, Nadon L, Richardson L, Gérin $M$. Cancer risk associated with 10 inorganic dusts: results from a case-control study in Montreal. Am $\mathcal{F}$ Ind Med 1989;16:547-67.

12 Office of Population Censuses and Surveys. 1970-2 occupational mortality: decennial supplement, England and Wales. London: Office of Population Censuses and Surveys. London: Office of Populatic
(Series DS No 1, 1978.I.)

13 Milham S. Occupational mortality in Washington State 1950-79. Cincinnati, OH: US Department of Health and Human Services, 1983. (Public Health Service DHHS NIOSH); No 83-116.)

14 Minder CE, Beer-Porizek V. Cancer mortality of Swiss men by occupation, 1979-82. Scand $\mathcal{f}$ Work Environ Health 1992;18(suppl 3):1-27.

15 Firth HM, Cooke KR, Herbison GP. Male cancer incidence by occupation: New Zealand, 1972-84. Int $f$ Epidemiol 1996;25:14-21.

16 Pukkala E. Cancer risk by social class and occupation. $A$ survey of 109000 cancer cases among Finns of working age. Contributions to epidemiology and biostatistics. Basel: Krager, 1995.

17 McDowall $M$. Cement workers and cancer: epidemiology at work [editorial]. Br $\mathcal{F}$ Ind Med 1986;43:505-6.

18 Norseth $T$. The carcinogenicity of chromium and its salts [editorial]. Br f Ind Med 1986;43:649-51.

19 Chromium, nickel and welding. IARC monographs on the evaluation of carcinogenic risk of chemicals to humans. Vol 49. Lyon: International Agency for Research on Cancer 1990.

20 Múraratal og steinsmisteinsmid́a. (Register of masons and stone cutters). Reykjavik: Múrarafélag Reykjavikur, 1967.

21 Jónsson T. Múraratal og steinsmida I og II. (Register of masons and stone cutters I and II). Reykjavik: pjóozsaga hf, 1993.

22 Tulinius H, Ragnarsson J. Cancer incidence in Iceland 1955-84. Reykjavik, Cancer Society and Director General of Health, 1987.

23 Breslow NE, Day NE. Statistical methods in cancer research Vol II-The design and analysis of cohort studies. Lyon: International Agency for Research on Cancer, 1987.

24 Blöndal A, Björnsson J. Spurningavagn Hagvangs hf. Arsskýrsla 1995. Reykjavik: The Committee for Tobacco Use Prevention, 1995

25 Turk K, Rietschel RL. Effect of processing cement to concrete on hexavalent chromium levels. Contact Dermatitis 1993;28:209-11.

26 Kristjánsson V. Króm $i$ sementi. (Chromium in cement.) Reykjavik: Fjölrit, 1984.

27 Eliasson G. Ákvöraun vatnsleysanlegs krómats. (Determination of water soluble chromium.) Reykjavik: (Determination of water

28 Kiilunen M, Järvisalo J, Mäkitie O, Aitio A. Analysis, storage stability and reference values for urinary chromium and stability and reference values for urinary chromium and

29 Graul RJ, Stanley RL. Summary reports. Specific gravity adjustment of urine analysis results. Am Ind Hyg Assoc $f$ 1982;43:863.

30 Huvinen M, Kiilunen M, Oskanen L, Koponen M, Aitio A. Exposure to chromium and its evaluation by biological monitoring in the production of stainless steel. Fournal of Occupational Medical Toxicology 1993;2:205-16.

31 Fregert S, Gruvberger B, Sandahl E. Reduction of chromate in cement by iron sulphate. Contact Dermatitis 1979;5:39-42.

32 Rafnsson V, Gunnarsdottir H. Mortality among professional drivers. Scand $\mathcal{f}$ Work Environ Health, 1991;17: 312-7.

33 Axelson $\mathrm{O}$, Steenland $\mathrm{K}$. Indirect methods of assessing the Med 1988;13:105-18. 